\title{
AMBIGUITIES IN IP OFFICE - AN APOPTOSIS IN KNOWLEDGE ECONOMY (KE) - PROGRAMMED DEATH OF ECONOMY, INDUSTRY OF A NATION
}

\author{
Milind V. Sathe ${ }^{1}$
}

\begin{abstract}
SUMMARY: Introduction 1. What is apoptosis?; 2. New incarnation of apoptosis in Knowledge economy; 3 . When and what can lead to fall of nation, its economy and industry in Knowledge economy? ;4. What can arrest fall of nations, deterioration of economy? How can we retain nation wealth and boost domestic distribution and redistribution of wealth? Is it possible?; 5. Interpretation of prevailing ambiguities in IP and Patent offices; 6. Scope for transparency in critical areas in IP/Patent offices:; i. Patent applications, filing of request for early publication and publication of applications; ii. What details should be published? iii. Information on Payment of Fees:; iv. Publication of filing of request of examination; v. Publication of examination report:; vi. IP or Patent office - A battlefield in KE; 7. Clarity about scope of authorities; 8. Patent backlogs, its impact, corrective action and promise for future:; 9. Feedback on working of patent; 10. Collection and publication of data related to working - Why?;11. What details should be included in this feedback?; 12. Certified Documents; 13. Filings during the Transition period and their records; 14. Cases where IP or Patent monopoly comes into existence based on administrative or procedural errors; Final remarks; References
\end{abstract}

ABSTRACT: Post globalization, domestic industry in DCs and LDCs, their economy, industry seem to be collapsing, sort of apoptosis, a programmed death. Although it is impossible to reverse the events, it is certainly possible to assert sovereign power by each and every subject of the nation and more specifically those involved in administration of IPR. Text of the law should be interpreted in context of its evolution so as to regulate the nation. Entities from developed world have strong financial muscle and are skilled in IPR game for many decades. They are monopolizing sectors of vital importance in DCs and LDCs and will cause suffocation of domestic industries. Domestic industries must know on real time basis in full about the progress of IP and patents in their country to secure areas for monopolization or to dilute wrongly granted or inappropriately enforced patents.

Transparency in IP office and in patent offices, their publications is of utmost importance to developed country or DC or LDC in Knowledge economy. This transparency is necessary to allow domestic industry to perform fearlessly to keep itself aligned with sovereign priorities. To ensure survival of domestic industry base, to erect and install solid industry, to strengthen domestic economy, to ensure better distribution and redistribution of wealth within the nation and to augment employment, various elements of subject population should consolidate and raise their voice so that IPR is administered for the reason for which it received social recognition and sovereign approval. Awake and arise, prioritize your nation first.

KEY WORDS Patent office, Compulsory Licensing, Apoptosis, Patent Backlog, Knowledge Economy, Identity Crisis, Identity Diffusion, Specification, Examination report, Working of Patent, Certified Documents.

\section{Introduction}

Plant and animal bodies experience a unique phenomenon of programmed cell death called apoptosis. Apoptosis takes place due to presence or absence of certain stimuli or due to failure of the cellular mechanisms that guard and ensure survival. As a result cell operates to kill itself.

When major portion of the globe which is dominated by almost $2 / 3^{\text {rd }}$ of nations either belonging to the category of developing or least developed nations, consented to intellectual property (IP) based trade frame and globalization, these nations have actually gave rise to techno-legal, techno-economic stimuli. These are new stimuli for

\footnotetext{
${ }^{1}$ Milind V. Sathe holds a Bachelor of Pharmacy (first class) and a Bachelor of Law, both from the University of Bombay (second class), serving as an intellectual property agent authorized by the Government of India and currently occupying the position of Deputy General Manager in IPM and Projects in Unichem Laboratories Limited. He also holds a PhD on Law from the Harley School of Law, having also obtained the following degrees in the post-graduate level: Diploma in Business Management at the Welingkar Institute; Postgraduate Diploma in Hospital Management \& Health Plan at the Symbiosis Institute of Business Management in Pune; Post Graduate Diploma in Patent Law and Practice at the Institute of Intellectual Property Studies in Mumbai.
} 
nation, its administrative, legal set up, the surviving abilities of the national economy, its industry. An imperfect understanding of happenings can cause fragmentation of economy and industry very much similar to what happens on cellular level during apoptosis. The new stimuli necessitate thorough understanding and interpretation strictly with the goal of ensuring national priorities. A little bit deviation results into impact that is against the national interest leading to apoptosis on national level. This happens because inadequate understanding and dysfunctional execution of IP laws of nation in IP based trade frame manifest in the form of putting big corporations from developed world in an advantageous situation. It directly diminishes or eliminates opportunities to industries and trade entities below certain threshold to survive. It incapacitates national entities by ensuring information block. It provides a very strong disincentive to national industry and national economy by promoting their closure and by providing opportunities for efflux of national wealth by way of royalty. It permanently disturbs existing channels of distribution and redistribution of wealth within the nation and installs new economic currents which siphon out national wealth by creating import dependency and by passing control on domestic market into hands of foreign entities.

This apoptosis is triggered by ensuring ambiguity in events and proceedings governed by IP offices more specifically patent offices of the nation. Ambiguity over areas of establishment of monopolies and procedures dealing with its administration, trade world, and industry is forced into confusion leading to either inability to take advantage of the situation or indulging into unwarranted risks which can be fatal enough to lead to dissolution of entity. In the bargain, nation starts depending more on imports. Exports slowly decline. Wealth oozes out of nation either as royalty or as profits flowing out or in sourcing of inputs at exorbitant prices. Increased forced imports result into loss of national wealth by several ways. Scope and opportunities to national industry severely diminish and their fate is tied more to in-licensing. And all this could have been avoidable, had there not been ambiguity, had there been execution of IP laws with national interest as rider.

Fundamental principle that national laws are designed for the benefit of nation is overlooked. Text receives prominence over context in which the text is derived.

\section{What is apoptosis?}

Apoptosis is a unique phenomenon, possibly first ever type of suicide ever existed and experienced by cell, a unitary living body due to presence or absence of stimuli. Presence or absence of stimuli sets in process of self destruction, many a times by engineering a malfunctioning of body system.

In knowledge economy (KE) variety of technical, legal, scientific stimuli are capable of creating a phenomenon on national scale and lead to decay and disintegration of national economy, industry in a manner similar to apoptosis on cellular level. There is a grave danger that nation, its industry, its economy may experience an apoptosis on much larger scale due to presence of specific industry oriented stimuli associated with knowledge economy and or due to absence of disciplined, oriented and well-functioning regulatory system that would not further decay and disintegration of national economy, industry. The impact of abnormalities in IP or patent offices is far reaching and irreversible. It leads to identity diffusion followed by identity loss, social unrest and loss of public tranquility. To know it well, we must know apoptosis in nutshell.

Apoptosis is a genetically determined process of cell self-destruction that is marked by the fragmentation of nuclear DNA. Attributes of apoptosis are: 
1) It is activated either by the presence of a stimulus or by the removal of a stimulus or suppressing agent;

2) It is a normal physiological process eliminating DNA-damaged, superfluous, or unwanted cells (as immune cells targeted against the self in the development of self-tolerance or larval cells in amphibians undergoing metamorphosis)...

This is called programmed cell death (MERRIAM-WEBSTER DICTIONARY, 2014).

In apoptosis cell uses specialized cellular machinery to kill itself (AUDIO ENGLISH DICTIONARY, 2014).

Apoptosis is orchestrated collapse of a cell:

1) by membrane abnormalities/malfunctioning/rupturing/blebbing,

2) by cell shrinkage,

3) condensation of chromatin, and

4) by fragmentation of DNA

5) followed by rapid engulfment of the corpse by neighbouring cells (BOOTH, Catherine; POTTEN, Christopher S.; RENEHAN; Andrew G., 2014).

Strong drugs e.g. Anti-cancer drugs, radiations like gamma or UV radiation, absence or disabled factors that support survival, lead to apoptosis. Autoimmune, muscular and neurodegenerative disorders have manifestation of apoptosis. Apoptosis is associated with many malignancies viral infections.

\section{New incarnation of apoptosis in Knowledge economy}

With wide spread of IP driven trade frame across the globe, the risk of apoptosis to domestic industry and its economy and to a nation, has grown manifold. The phenomenon is similar to steps described above:

1) abnormalities associated with IP and patent administration

2) shrinkage of domestic production and redistribution of wealth within the nation due influx of imports of IP protected goods

3) condensation or reduction of open areas, i.e., freedom to operate due to lopsided interpretations of IP national laws and absence of well structured, sovereign oriented IP offices, due to absence of effective procedures to guard national priorities, due to defective execution of existing procedures, what ever are they;

4) resulting into monopolization of domestic sectors of vital importance and fragmentation of domestic industry base, rendering the erstwhile inherently stable economies into porous, highly dependent fragile economies;

5) leading to rapid engulfment of domestic entities by neighboring foreign entities.

\section{When and what can lead to fall of nation, its economy and industry in KE?}

In 90's it was clear that globe is heading to internalize almost identical IPR trade frame. Despite glaring inherent differences in economy, in infrastructure, national product, industrialization, skill sets available. TRIPs brought all nations onto same trade platform.

For past almost two decades, we are in the era of globalization. For a poorly equipped nation, globalization is actually a trade invasion. It is a very graceful and polished term which in reality replaces age old harsh term "invasion". Globalization has replaced physical / geographical / territorial invasion by intellectual invasion. Intellectual invasions are implemented and executed via native or local administrative, legal and policing machinery and by members of subject population of the nation, by 
their alignment with international agreements. This is achieved by propagating lopsided interpretations of IP and IP laws, not in conformity of national priorities and domestic needs. The heterogeneous versions of intellectual property rights (IPR) are ably propagated by inadequacies and ambiguities prevailing in administration of IP through IP offices, inadequately trained legal/IP resources. Ultimately nation is sure to experience intellectual invasion, increased imports, reduced exports, loss of domestic industrial production and trade, phenomenally reduced domestic distribution and redistribution of wealth, rising deficits in import export trade and rising exodus of national wealth. Many nations which have recently internalized and consented to globalization, to lopsided IPR based trade frame or have unilaterally misinterpreted or inadequately interpreted globalization have started experiencing this beginning of apoptosis in KE.

It is fact that economies of Least developed countries (LDCs) and Developing countries (DCs) are exposed to and experiencing unilateral forces of rising imports, diminishing contribution in world trade, failure to expand the variety of commodities on export lists barring exceptional nations. Industrial expansion and domestic consumption of domestically produced native goods is diminishing. Various international agreements, free trade agreements (FTAs) and Regional agreements have further restricted the freedom of native industrial entities to operate within the territorial boundaries of the any nation. Erstwhile protectionist measures are no more useful. New concepts of IPR based trade frame have long lasting impacts. An inadequate and out of reference interpretation of international agreements and IPR laws is often prejudicial to native industry and have potential to cause social exclusion ultimately leading to loss of national identity.

Abnormalities in IP administration make the national trade and industry environment unpredictable and domestic industry suffers the most. Ambiguities act like land mines and hidden explosives, unwarranted risks jeopardizing existence of domestic trade or industry entities due to uncertainty impacting decision making.

In KE, ambiguities prevailing in IP/Patent offices of DCs and LDCs crate a very dangerous situation for the native industry which is relatively new to IP games. Weak position of native industry is further deteriorated by relatively strong position of trade and industry entities from developed world which are used to IP games for several decades. Absence of legal precedents in DCs and LDCs further complicates the situation by augmenting the possibility of adopting heterogeneous foreign decisions instead of adapting it to suit native needs. Very cautious approach is necessary for appropriate interpretation of national laws and their implementation, to build relevant precedents useful to build national industry and reinforce national economy. A lethargic approach augments ambiguities in IP regime and in the bargain, relatively tiny native industry members dare not engage in new operations. Native industry relies on sure option of being a converter, a toll manufacturer to serve a foreign entity. This approach severely limits abilities of native industry to earn profits and provides full opportunities to foreign entities to maximize their profits. Profits finally find their way out of nation, escape from national channels of distribution and redistribution of wealth.

There starts a shrinkage of domestic industrial activities and so starts shrinkage of economy. A study websites of some IP offices of Asia and South East Asia shows that premium industry sectors are monopolized by foreign entities. In short in the near future, premium industry in these nations will heavily depend upon foreign monopoly right holders and so will depend the nation. Issue is how these monopolies have come into existence? Were all rules and laws which were designed for national priorities, followed? Are they followed now? 
Reduction in industrial activities, rising imports, diminishing exports, unconventional channels of distribution and redistribution of wealth not favoring the nation, lead to social exclusion and social discontent, question the political will, jeopardize public tranquility and spread political instability. Tragedy is that, to combat ill situation of political instability, again foreign interference is relied upon. This is a one way, irreversible path to doom, where the nation, its industry and economy is irreversibly fragmented. This is fall of the nation.

\section{What can arrest fall of nations, deterioration of economy? How can we retain nation wealth and boost domestic distribution and redistribution of wealth? Is it possible?}

Yes it is possible to arrest the fall of the nation. It is possible to ensure distribution and redistribution of wealth within the nation.

Transparency in IP offices and interpretation of IP laws with the knowledge why are they designed the way are designed, or that they are designed not to harm domestic industry and subject population is of paramount importance for the industrial, economic progress of any nation, for political stability and social tranquility.

Another remedy is propagating patriotism and national spirit in personal and social life where subject population is encouraged to use anything and everything that is made by the domestic industry. Discouraging consumption of foreign brands is necessity to support domestic industry and national economy.

This scenario arising from failure to keep pace with changes forced by IPR regime, necessitates thorough introspection, review and scrutiny of:

i) context in which the national IPR laws were amended,

ii) preamble and presumptions in the constitution of the nation,

iii) kind of material infrastructure, kind of human capital available vis-à-vis the level of material infrastructure nation wants to achieve in predefined period,

iv) extent of training imparted to IP office executives, whether the training is suitable and apt for local needs or it is a training imparted by some foreign IP office which enforces foreign law as per the standards present in that foreign country,

v) manner of implementation and enforcement of IPR laws and

vi) most importantly extent to which apex institution in each nation has realized the critical role of IP or Patent Offices in the nation.

It is necessary to clearly understand why are the laws the way they are, how and why they emerged, were they designed to favor a patentee or were they expected to retain and ensure balance of public and private interests. Clarity on these aspects will decide to a great extent the ability of judicial and quasi judicial authorities to interpret the relevant provisions in IP laws, Patent laws and the manner of enforcement. A clear understanding on these issues will help in improving the transparency in IP administration and enforcement.

Several national entities, in developed countries, DCs and LDCs should vigilantly monitor operations, procedures, processes, transparency and practices in IP offices and Patent Offices. Critical national entities are mainly IP educated individuals and their organizations, native industry, IP offices themselves and their audit cells, international organizations (such as medicines sans frontier) and social organizations within the geographical boundaries of the nation because IPR based trade frame has potential to debilitate economy of the nation, create social and political unrest. It is bound to create identity diffusion and identity crisis (SATHE, Milind V., 2012, 138-141). 
In fact subject population of the nation including IP and Patent Office employees must presume that IP or Patent Office is established to further sovereign interests, public interest, ordre public and the balance of public and private interest (SATHE, Milind V., 2012, 160). TRIPs signed by so many nations refers to balance of rights and obligations in Article 7. No nation enacts laws and Acts to suppress sovereign or local interests. Acts and Laws, a sovereign expression, are enacted by any nation to ensure that nation progresses freely and fearlessly. IP offices should never contradict sovereign priorities. A nation is empowered to enact and an IP office or patent office in specific is empowered to enforce any provision, not contradicting international agreement and law of the land. Absence of any specific stipulation or provision should be interpreted to the benefit of the nation and its priorities. Transparency is prerequisite to ensure balance of interests. Transparency creates by default necessary pressures to align IPR with national priorities.

Therefore each new signatory to TRIPs and such other international agreement must ensure that IP offices maintain 100\% transparency about the prosecution details and status of IP application or grant.

\section{Interpretation of prevailing ambiguities in IP and Patent offices}

Areas related to dissemination of information related to IP or Patent application, their enlisting/recording/registration, processing/prosecution, office actions and responses to office actions, enforcement, licensing, assignment, grant of the patent monopolies on fulfillment of criteria as stipulated, history of patent working and to adjudication or deciding disputes related to establishment or enforcement of patent monopolies and litigation should be $100 \%$ transparent. There must be linkages available on IP office website or Patent office websites leading to judicial decisions or to various levels of courts where the IP or Patent cases are tried and decision delivered. Reader should introspect and compare the scenario in his country with respect to points indicated in the article and evaluate the extent of available updated information in his nation.

IP office in general or patent office in specific is not created to discourage the native industry or to promote monopolization of native industry by the foreign ownership. IP office and patent office in specific should clearly display on their website their affiliation and devotion to motherland and their objective to be promoting native industry to next higher level. They must also state that this objective would be achieved by promoting and disseminating information on patent applications and their prosecution and by implementing the procedures to achieve the TRIPs objective as stated in TRIPs Article 7. Accountability for performance has to be clearly established right upto ministerial level in apex institute.

IP office or patent office is expected to further national interests, promote national economy and trade while honoring national treatment. Term national treatment has to be understood well. It is a bilateral phenomenon and not unilateral. An entity which expects a national treatment from sovereign should be made to understand that such treatment is reciprocal. An antinational performance by an entity or a performance against the sovereign priorities or against the constitutional provisions should deprive such an entity of the monopoly or trade privilege by identifying the entity as enemy of the nation (SATHE, Milind V., 2012, 281-286). IP offices and patent offices in specific should voice and propagate the cardinal principle that no international agreement places IPR holder above sovereign. Sovereign reigns supreme and is undisputable within its 
territorial boundaries. Transparency in IP office and patent office automatically aligns IP office and patent office operations to national priorities.

Absence of transparency in IP offices and Patent offices indicate that there exist some other priorities which supersede national priorities. It indicates the extent of scope for alignment of priorities and for improving operations and processes so that nation can be benefited. Absence of transparency also indicate that IP or patent offices are not reliable, albeit are entrusted with critical operations impacting trade, economy, industry and social tranquility within the nation. Absence of transparency indicates that nation is sitting on volcano that can erupt any time. It indicates that apex administrators in the nation need to understand adverse impacts of absence of transparency. Predictability and faith in the nation, its laws and enactments conforming to international agreements is jeopardized by lack of transparency in IP and Patent Offices administration.

It is often said that if at all any granted monopoly is disputable; a business rival would litigate and uproot it. However this argument forgets the fact that men, money, machine and material spent in deciding such cases deprives the nation of effective utilization of resources which otherwise could have been spent on deserving dispute. It adds to the cost of initiating and maintaining IPs. Besides inflating costs of IP related transactions, it creates ambiguous environment that discourages industry. Society has to pay the cost of ambiguities in IP offices or patent offices.

\section{Scope for transparency in critical areas in IP/Patent offices}

\section{i) Patent applications, filing of request for early publication and publication of} applications:

There are two types of patent specifications, a provisional and the final or complete. It is complete or final specification which is published by Patent office after a stipulated interval as dictated by Patent enactment of the nation. Provisional is not published and is pleaded that it is a private dialogue between an inventor/applicant and the patent office. I strongly propose that provisional specification should also be published. Logic is that if there is no amendment between provisional and final specification, it would amount to publication of provisional specification, albeit termed as complete/final specification. If provisional specification is filed but complete/final is not filed, then society has paid the cost for the inventive work done within the society, in receiving and maintaining the provisional in records and hence it must be communicated to society. Very fact that provisional specification is made means there was intension to secure the monopoly. IP or patent offices have been engaged. Society has paid the cost for maintaining Patent office. Society has to be duly reciprocated and compensated. If there is a change between provisional and final specification then nothing should logically prevent patent offices from publishing provisional specification as it would add to and enrich public domain which in turn will benefit the native industry, economy and nation. Not publishing provisional specification is a foreign concept and no international agreement is capable of preventing sovereign regulation of publishing provisional specification if sovereign so desires.

\section{ii. What details should be published?}

This is a very critical and significant aspect that directly impacts industry, economy of the nation.

Titles of inventions and abstracts are some times so ambiguously worded in the tiny word limits set by law of the land, that it is practically impossible to 
correlate if the invention and patent application with the target. Publications of abstracts of patent application after stipulated interval are useful only if they show essential features of the invention and provide information about the applicant, inventors, priorities, classification. A publication of abstract without figure or diagram may not be useful enough. There has to be some provision which will insist that abstract must directly contain main claim. I would propose that law should insist that abstract should be more than 150 words.

It is essential that publication of specifications should enable reader to access the structural formulae and diagrams.

Claim statements displayed on website should be the latest and final claim statements. Displaying old and irrelevant claim statements which have undergone amendment during prosecution or after response to office action should be construed as misguiding the nation and patent offices should be asked to identify accountable and responsible employee. Paper, hardware and software systems and packages present and used in IP offices must confirm to essential attributes of identity, traceability and reproducibility. Each and every transaction and act from patent application to publication of any document be it a specification, prosecution history or anything related to IP/patent should be capable of being identified as to who did it, when was it done, preceding event and the event is followed by which event and how was it done.

When a request for early publication is filed, it should also be published.

Publication of search report, examination report, office action of any nature, response to examination report or office action, resulting amended documents with legible details of date, time, who initiated and responded, when responded and updated status is of critical nature for quick processing of IPR, for quick industrial output and to build robust, rugged and potent economy in KE. Any failures in these respects can be interpreted as an act against the sovereign.

It is of paramount importance to publish or to provide workable linkages to court decisions related to IP or patents in specifics and patent office should own that responsibility.

There has to be clear notice on IP or patent website to win a prize by showing a difference in soft displays and paper files in IP or patent office. Efficiency, evaluation and rating should be directly related to number of differences / errors found in soft displays and paper files and the ambiguities surfaced. These differences and ambiguities should not penalize subject population of the nation in any manner.

iii. Information on Payment of Fees: This should be accessible.

iv. Publication of filing of request of examination: Details of filing of request for examination should be published as to who filed, on what date filed, how the fees were paid, when the fees were paid. There should be no difference in web display and paper file.

v. Publication of examination report: For each and every examined application, examination report should be accessible in soft form. Examination reports and the responses should be date wise chronologically arranged, legible and downloadable and accessible.

\section{v. IP or Patent office - A battlefield in KE}

All requests made above are logical, simple. But despite being so logical and simple, why are there lacunae in the information that is available on IP office websites? Why there is difference in what is displayed on website and what is present in the paper file? How's that nobody is identified and held accountable 
for the variation? How many of readers belonging to various nations are sure that each and every application was published as per the law when the nation was going through transition phase? It is necessary that electronic records as shown on website of IP/Patent Office and paper documents or hard copies present in the paper document files are identical. There have been reports that sometimes what is shown on website is not supported when a file inspection is ordered. Converse is also true. It is also reported that even if some paper is present in paper document file, it is not displayed in soft form on website. E.g., it is experienced that no hard paper request for examination was present in the file but the website showed that application is awaiting examination. It is necessary that when a certified copy of the patent is asked for, an updated copy in which all amendments have been given effect should be supplied. If the patent office supplies a copy which is not updated, then the basis on which pleadings are made, analysis and defense is to be done becomes problematic. This is because patentee refers to one version and patent office provides another version to other party. This results into unfair treatment to recipient of improper version. Besides, recipient may not be able put adequate efforts and is bound be defeated. Such failure of the native firm because of the ambiguities in IP / Patent office will ensure exodus of national wealth into foreign hands at the same time it will deprive domestic or native industry from engaging into industrial operations. This will jeopardize distribution and redistribution of wealth within the nation. Therefore, it is all the more necessary to realize that access to correct information is a patriotic, moral and ethical duty of IP or Patent office executives. Employees in patent office are solders to fight intellectual invasion and protect the motherland from onslaught. IP / patent offices are in reality the battlefields in KE. Each subject of every nation should be vigilant enough. IP office employees carry the responsibility. So also employees in law ministry, enforcement ministry and in IP offices are IP solders. They must blow whistles when required.

It is necessary to create awareness about serious consequences and social cost paid by society due to these discrepancies and ambiguities. It is necessary to publish / publicize that valuable time of judiciary is spent in litigating which otherwise could have been saved. Engaging judiciary, industry, legal professionals on an avoidable cause is actually depriving nation from resolving other priority issues. It is a social evil and should be labeled so. Adequate publicity should be given across the subject population in each nation to create public pressure and to discourage such discrepancies. How are we going to make sure and auditable that every patent application is published sequentially or in chronology especially in the transition phase. Is there a sound justification for lapses in transition period? Apex institution should demonstrate the importance it gives to IP Office processes by including such discrepancies in departmental audits / reports, should address and resolve. Otherwise subject population will not hesitate to form unfavorable opinion about IP / Patent office executives, administrators, ministers and insensitive apex institute. It is going to sow seeds of dissatisfaction among subject population and industry of the nation. It will question the ability of the apex institute to safe guard the regional freedom and sovereignty.

IP / Patent offices should boldly display charts of Industrial or Economic goals for next " $x$ ", " $y$ " or " $z$ " years and real time position of industry or industry segment or economy of the nation on those indices and relevance of those 
indices. The difference in the indices forms a strong ground of interpretation of emergency situations. This is useful in Compulsory Licensing cases.

\section{Clarity about scope of authorities}

This issue is of paramount importance in case patent monopolies and in case of pharmaceutical monopolies in specific. DCs and LDCs have engaged themselves in blind adoption of IPR laws and pharmaceutical regulatory norms from developed world for whatever (?) reasons such as IPR climate is new to most of them. In developed world IPR and pharmaceutical regulatory aspects have been mixed, possibly it suits their system and satisfies their needs. DCs and LDCs are in different level of infrastructural achievements, different skill sets present within and have altogether different set of needs and different priorities. DCs and LDCs should design their own mechanism to resolve the new issues arising after internalization of IPR regime. What is required is adaptation and not adoption.

Prevailing situation in DCs and LDCs is most fertile climate to create confusing precedents which will shadow their future. Judicial and quasi-judicial adjudications based on inadequate inputs are an ever hanging threat. It is likely that decisions may penetrate into some other area over which they do not have authority and this will happen due to inadequate knowledge about functioning of different departments and the laws governing these new departments. Under no circumstances any litigation related to pharmaceutical patent should be allowed to take shelter of happening or event in some other department. There are very many chances that IPR and patent litigations would be intentionally or unintentionally correlated to some issues in food and drug regulatory rules and regulations. The purpose would be only to use patent monopolies for the benefit of patentee UNILATERALLY. There are about 21 such new issues that shall be experienced by DCs and LDCs have been listed in my book (SATHE, Milind V., 2012, 149).

\section{Patent backlogs, its impact, corrective action and promise for future}

All nations suffer from patent backlogs (SATHE, Milind V., 2014b; JAGDALE, Sachi; 2014). The phenomenon is more prominent in case of developing countries like India. Failure to attend and examine patents may mean at later date some entities would be prosecuted and fined for infringement. This creates uncertainty. To avoid this complexity some companies may not indulge into potential business sectors at all. Thus subject population may not be able to produce goods domestically, although they may not be infringing. It means forcibly nation may have to use goods controlled by patent applicant who may or may not be granted patent. This is especially true if backlogs run into 3 years or more.

This is a phenomenon of creating an artificial scarcity of goods in the nation. Not necessarily every patent applicant engages into manufacturing activity. Therefore such patent applications would be barrier to progress of the nation. Who should find out solution to the problem? Do IP / Patent offices have any role? Yes. I expect readers to think about the role.

Patent backlogs can be reduced by providing some infrastructure related to searching of databases. The job can be split into activities of prior art searching, thereafter rating or evaluating the application and communicating the findings. It is worthwhile to exploit the options of appointing searching centers and examiners on contract, preferably state owned research institutes. In a nation where adequate skilled 
population is available, any excuse by ministry controlling IP and patent office would be unacceptable. It is detrimental for domestic industry. In DCs and LDCs domestic industry players are not as big as those in developed world. Therefore financial muscle power of domestic industry members is limited and that disables them from taking risks. Employment and clearance of patent applications should dynamic enough to allow backlog not exceeding the number of patent applications for which the request for examination was filed in preceding say 12 months. Appointment / reappointment of examiners should be planned accordingly. In fact backlog is a blessing in disguise to create infrastructure for searching skills and organizations. These organizations would then be helpful to several Government owned industries, educational institutes, in proliferating home and cottage applications of technologies.

A delay by applicants in putting the applications in order, also adds to backlog. IP or Patent office should publish information stating steps taken by it to reduce the back log. At stipulated interval actions taken and how much of pending applications have been cleared or examined should be published. It must be published if the backlog is in line with expectations which should not exceed say 12-14 months.

\section{Feedback on working of patent}

Working of patent is of critical importance (SATHE, Milind V., 2014a) and is essential to keep it enforceable. Publication of working of patents seldom finds the place or rather never finds any place on websites of IP offices and of patent offices. My interaction with IP professionals revealed that this is not done because IP / Patent offices in developed world don't publish this information. This justification for not publishing the details of working of patent is ridiculous. Is any law in your nation stops IP / patent offices from publishing this information? Which law prohibits it? Which international agreement prevents IP / patent office from publishing this information? Isn't there a provision in law of your nation which makes it necessary for the IP holder or patentee to work his invention in the period which is equal to or related to Article $5 \mathrm{~A}$ (4) of Paris Convention? ${ }^{2}$ There has to be provision on IP or Patent office website that would boldly display the list of invention not worked in 3 years after grant or in 4 years after application.

Implications of such publication are far reaching and are of tremendous benefit to the nation concerned. In KE, despite having Paris Convention Article 5 A (4) in some or the other form in law of the land, patent offices of all nations are coincidently inactive and docile about it. Effect of this inactive gesture of patent office is again the cost that is paid by society in litigating if a particular patent is fit for Compulsory Licensing (CL) or not. Such litigations last for about 3 years or more albeit it is related to alleged "emergency" which very few laws have defined directly or indirectly. After lapse of 3 years nation reaches to a decision that a particular patent is open for CL. Publication by patent office of list of patents not worked in the country will automatically eliminate the inordinate unproductive delay of $3+$ years and emergency can be dealt with in realistic sense.

\footnotetext{
${ }^{2}$ Article 5 A (4) (4) A compulsory license may not be applied for on the ground of failure to work or insufficient working before the expiration of a period of four years from the date of filing of the patent application or three years from the date of the grant of the patent, whichever period expires last; it shall be refused if the patentee justifies his inaction by legitimate reasons. Such a compulsory license shall be non-exclusive and shall not be transferable, even in the form of the grant of a sub-license, except with that part of the enterprise or goodwill which exploits such license.
} 


\section{Collection and publication of data related to working - Why?}

This is not identical to preceding text. This publication informs reader about extent of working whereas preceding text deals with patents not worked.

IP Office and Patent office of each and every nation should have provision to collect the data on working of IP and working of patent. In KE where generation, dissemination and use of knowledge hold the key to achieve sovereign objectives, apex institute should have appropriate laws in place where control over knowledge is not misused. Getting feedback on working of IP and Patents and publication of this data is of paramount importance. It is logical that not every patent can be worked within this period. Normally when working of a patent is capital and or labor and or technology intensive it may not be possible to work the patent within this period stipulated by Article 5 A (4) of Paris Convention or similar provision in the law of the land. But this should not be interpreted as total freedom from conditions of working of patent. Unlimited freedom would never allow dissemination of technology, development of skills and development of satellite industries. If patentee is aware that patent cannot be worked due to reasons stated above, logically he should not apply or if he applies and granted a patent he has to conform to regional requirements of working of the patent to ensure adequate supply of patented article at affordable price or clarify why he could not work the patent in the stipulated period. It is this data and submissions of the patentee which need to be published by Patent office. It is the responsibility of the apex institute of the nation to ensure that patentee's behavior does not discourage development of native or domestic industry, markets or discourage exports.

\section{What details should be included in this feedback?}

Every patent office can seek different particulars related to working of the patent/invention based on law of the land. But there are some critical points on which the feedback has to be sought from the patentee and MUST be published. The essential aspects which must be declared by patentee and published by IP / Patent office are as follows:

i) Name address and nationality of the patentee and or assignee

ii) Date of patent application and date of grant

iii) There has to be a FORM / structured input of communication from patentee which he has to submit at the time of grant and it should indicate submission by patentee as to when he will work the patent, and the justification for delay if any. This submission should have evidential value.

iv) Is the patent is worked within 4 years from the date of application or within 3 years from the date of grant whichever later? This has to be communicated to patent office without failure in first 3 years after grant or for a justified extended period.

v) Subsequently every year, working details of past 3 years should be submitted by patentee. Quantum of working in terms of number of units produced and extent of capacity used. How much of public requirement is met and the logic for this calculation.

vi) If the patent is not worked why it was not worked and when it will be worked. This has to be communicated to patent office without failure in first 3 years after grant and subsequently when applicable.

vii) Is the working of patent is achieved by importation of the patented article. Quantum of patented article imported. Importation of miniature or insignificant 
quantities should not be construed as working of the patent. Any pleading based on importation of insignificant quantities of patented article should be construed as an activity to defeat the purpose of law and should not be given any legal weightage. Rather an activity performed to defeat the purpose of law should be dealt with accordingly.

viii) If the patent is licensed? If the patent is not worked by patentee why it is not licensed out? What efforts were made by patentee/assignee to license it out?

ix) If the patent is not worked, not licensed out, should it be considered to have industrial application? Why?

x) What are the plans for price reduction? How much price will be reduced in next 4 years?

xi) If the patent is not worked in 4 years from the date of application or within 3 years from the date of grant why the patent should not be compulsorily licensed?

xii) Is non working of patent in conformance with related provision of the law of the land? How?

The details collected from patentees must be reviewed/audited by patent office. Review should result into actions which would either keep the patent monopoly alive, indicating that patent shall be worked or would result into official declaration that patent is open for CL or is not conforming to law of the land or dilution of the monopoly by other appropriate means present in the law of the land or as suggested in the foregoing text such as neutralization. The declaration should be an official notification listing patent numbers.

\section{Certified Documents:}

Various classes of documents are required in the form of certified copies. These include patent applications/specifications, office actions, responses of applicant, granted and amended patent documents, re-issued patents, various filings made during transition periods and their prosecution records.

To get the certified document from the patent office is necessary and the number of documents requested will keep on rising as IPR based trade is bound to rise and grow in all dimensions in all nations. There should be mechanism whereby an aspirant should be able to key in details of the document required and on payment of requisite fees, he should be able to download the said document as certified copy. The printout of such document should be admissible in the court of law as undisputable evidence. There should be means to identify authenticity of this document. There should be trail and traceability. A system that conforms to basic criteria of identity, traceability and reproducibility should be installed and used by IP and Patent Offices in each and every country.

This system does away with human interference, human involvement, dependence and the drawbacks thereof, and the difficulties associated. In $21^{\text {st }}$ century if bank transactions of huge value can be done electronically, why should we restrict the performance of IP and Patent offices by insistence of paper seals? Why load IP and Patent offices with manual job which can be easily done by modern means? An automatic system would also reduce unproductive load on IP or Patent Office employees and will directly help in clearing the backlogs, quick resolution of pending cases. It will increase output of IP and Patent offices, augment the rate at which cases are decided, will lead to quicker resolution of cases and allow industry to perform.

Such desired access for certified documents should be easy on payment of required fees by electronic means. 


\section{Filings during the Transition period and their records}

This is a very delicate yet very important issue. While DCs and LDCs transitioned from pre 1995 to post 1995 IPR regime, several amendments were done in laws related to IP and Patents in specific. Amendments were also done due to DCs and LDCs becoming signatory to various FTAs, RTAs. These changes had created a complicated and complex situation in IP and Patent offices. Receiving and processing of these applications during the transition phase is of great importance. It is critical that all documents are processed meticulously and are rendered accessible easily. There has to be a thorough audit of application received during the fag end of the transition period. Any errors in processing these applications are actually dents on national industry and economy. LDCs will experience same complexity and same effects on their economy and industry.

\section{Cases where IP or Patent monopoly comes into existence based on administrative or procedural errors.}

Where the errors were/are known to IP or Patent Office and the applicant, or are brought to the notice of IP/Patent office or public platforms, the IP or patent monopoly should be summarily neutralized by law. I am purposely using the word neutralized as the procedures to resolve the issue may be different from opposition or invalidation or revocation. The issue can be addressed either by keeping IP or patent live but with no exclusionary attribute and making patentee to renew it for entire validity period of 20 years. Alternatively patent may be declared null and void ab initio or with provision to revert profits earned, to the Government.

It is pertinent that IP offices and Patent offices of all nations should declare the areas and extent of transparency they intend to achieve and in the period within which they intend to achieve as their objective and goals to be achieved.

Failure to acknowledge the long lasting and far reaching impacts of ambiguity in IP and Patent offices, on economy and industry of the nation is promising the apoptosis of the nation. Will you be a part of it or you will like to save your nation?

\section{Final remarks}

IPR onslaught from entities from developed world which have very strong financial muscle and which are used to IPR game for many decades, is suffocating domestic industries from DCs and LDCs. Sectors of vital importance in DCs and LDCs are being monopolized by foreign entities. This monopolization will hardly allow domestic industries to perform. Domestic industries need to know on real time basis in full about the progress of IP and patents in their country. Knowledge of real time status of IP and patent prosecution will allow them to secure areas for monopolization or will encourage them to dilute wrongly granted or inappropriately enforced monopolies. Transparency in IP office and more specifically in patent office administration, their publications is of utmost importance in every nation independent of it being developed country or DC or LDC is necessary in KE. This transparency is necessary to allow domestic industry to perform fearlessly to keep itself aligned with sovereign priorities. To ensure survival of domestic industry base, to erect and install solid industry, to strengthen domestic economy, to ensure better distribution and redistribution of wealth within the nation and to augment employment, various elements of subject population 
should consolidate and raise their voice so that IPR is administered for the reason for which it received social recognition and sovereign approval. Awake and arise, prioritize your nation first.

\section{References}

AUDIO ENGLISH DICTIONARY. Available on:

http://www.audioenglish.org/dictionary/apoptosis.htm. Accessed on: 13th jan. 2014.

BOOTH, Catherine; POTTEN, Christopher S.; RENEHAN; Andrew G. What is apoptosis, and why is it important? Accessed on: 13th jan. 2014.

http://pharma.financialexpress.com/sections/management/1521-patent-backlog-aqualitative-analysis. Accessed on: 13th jan. 2014.

JAGDALE, Sachi. The patent pileup. Express Pharma. Available on:

http://pharma.financialexpress.com/sections/market-section/1252-the-patent-pileup. Accessed on: 13th jan. 2014.

MERRIAM-WEBSTER DICTIONARY. Available on: http://www.merriamwebster.com/medical/apoptosis. Accessed on: 13th jan. 2014.

SATHE, Milind V. Compulsory Licensing in Knowledge Economy - it is NOW or NEVER - What, Why and When about CL. New Delhi: Satyam Law International, 2012.

Non-working of patent a blot on knowledge economy. Express Pharma.

Available on:

http://pharma.financialexpress.com/sections/management/1271-non-working-of-patenta-blot-on-knowledge-economy. Accessed on: 13th jan. 2014a.

Patent backlog: a qualitative analysis. Express Pharma. Available on:

http://pharma.financialexpress.com/sections/management/1521-patent-backlog-aqualitative-analysis. Accessed on: 13th jan. 2014b. 